\title{
化粧品関連分野における液体クロマトグラ フィーの応用
}

\author{
木沜敬二
}

最近, 化粧品関連分野に和ける高速液体クロマトグラ フィー(HPLC) の応用は急激に増加している。化粧品関 連分野と一ロに言ってもクリーム, ローション, シャン プー, 口紅, コールドウェーブ溶液, 紫外線遮断剂, 一 アダイ，ハミガキなどその範囲は広い。またこれらの成 分原料も界面活性剂, 油性成分, 粉体, 高分子化合物, 紫外線吸収剂, 殺菌防腐剤, 色材, 牤よび香料など多様 である。従って，化粧品関連製品からこれらの成分原料 を分析するには, 従来からの液体クロマトグラフィーを 用いる方法では種々の困難性をともなう。しかし, 先に 述べた様に近年開発された HPLC を利用することによ り，多くのデータが提供されている。特に HPLC は分 析の迅速性と高性能分離に特長がある上に, 高感度性も 具備しているので, 微量成分の分析にも適し, その応用 性は止まるところを知らない。

既に皆様は御存知のことと思われるが， HPLC を利 用する上に充てん剂の選択は非常に重要である。

ここでは紙面の都合も考光, この分野で利用される充 てん剂についての基礎的な解説を試み，ついで化粧品分 野における HPLC の応用例を示すことにする。

\section{I 充てん剤について}

クロマトグラフィーは, 吸着, 分配クロマトグラフィ 一を初めゲルバーシェーション，イオン詨，イオン交換 执よび錯体クロマトグラフィーなどに分類できる。イオ ン交換クロマトグラフィーについてはよく御存知の方も 和られるかと思らので, 化粧品の分野にイオン交換ク口 マトグラフィーと共隹用される吸着, 分配クロマトグ ラフィーについて述べることにする。特に最近ではイオ ンペアークロマトグラフィーの応用例も多い。

\section{1. シリカゲル充てん剤など}

シリカゲルは吸着クロマトグラフィーに用いられる 他, 分配クロマトグラフィーなどにも利用される最も一 般的な充てん剂である。

シリカゲルはケイ酸ナトリウムと鉱酸との反応によっ て得られるが, 反応条件によって種々の異なった性質の

国立衛生試験所：東京都世田谷区上用賀 1-18-1
ものを得ることができる。シリカゲルの表面はシラノー ル基があり，これに水が配位して，つぎのような構造を していると言われている。<smiles>C[SiH](O)C[SiH](C)[SiH](C)O[SiH]1O[AlH][SiH](C)O[SiH2]1</smiles>

ところで, 充てん剂は, カラムの固定相に和ける物質 の拡散する距離を，出来るだけ短かくするために，通 常, 全多孔性和よび表面多孔性充てん剤の二種類が市販 されている。前者は, 大きい多孔性表面積の保持体に固 定相を保持させたもので, 直径 5 〜 $10 \mu \mathrm{m}$ である。また 後者は約 $30 \mu \mathrm{m}$ のガラス球の表面に多孔性の層を作った ものに固定相で被ったもので, この多孔性の層は愿さは 約 $1 \mu \mathrm{m}$ である。

これらのシリカゲル充てん剂の市販品を紹介すると, 主なるのはつぎの通りである。

全多孔性…Lichrosorb SI 60, 100, Merckosorb SI60, 100, Micro Porasil, Porasil, A F, Sil-XI, Spherisorb S5W, Vydac 101TP, Wakogel LC-H, Zorbax Sil, Bio Sil A, Hitachi Gel 3040, IATROBEADS 6RS, JASCOSIL SS etc.

表面多孔性…Zipax, Corasil I, II, Pellosil HS, HC, Vydac Adsorbent, etc.

その他アルミナ充てん剤がある。これは, 酸性, 中性 特よび塩基性の 3 種のタイプがあり, 分析上, 目的とす る物質に適したタイプが使用できるようになっている。 また活性炭充てん剂も利用されている。

\section{2. 化学結合型充てん剂}

これらは一般的には分配用充てん剂として使用される ことが多い。現在，固定相の保持体にはシリカ系のもの が用いられている。この結合型充てん斉にはアルキル基 結合シリカゲル，アミノ基和よびニトリル基結合シリカ ゲルなどがある、アルキル基結合シリカゲルのらちで, オクタデシル基 (ODS) の結合様式の例を示すとつぎの 通りである。 
有機クロルシラン 例党ば<smiles>CCC(C)(C)Cl</smiles>

とシリカゲルが反応して得られる<smiles>C[SiH](O)O[Si](C)(OC(C)(C)CC(C)(C)C)O[Si](C)(C)O</smiles>

などである。

この ODS のタイプの市販品は主なもの㳊つぎの通り である。

Lichrosorb RP-18, Zorbax ODS, Permaphase ODS, $\mu$-Bondapak $\mathrm{C}_{18}$, Bondapak $\mathrm{C}_{18} /$ ポラシルBなど

悉农, この他結合固定相がニトリル, エーテル, ポリ エチレングリコールなぞが㐫る。

例光ば, エーテルでは, Phermaphase ETH, ポリエ チレングリコールではDurapak Carbowax 400/Corasil, ニトリルでは Vydac polar Bonded phase などがあ る。

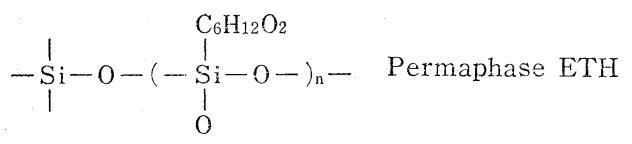
$\begin{array}{ll}\mid & \mid \\ -\mathrm{Si}_{1}-\mathrm{O}-\mathrm{Si}_{\mathrm{i}}-\left(\mathrm{CH}_{2}\right)_{3} \mathrm{CN} & \begin{array}{l}\text { Micropak CN, } \mu-\mathrm{Bon}- \\ \text { dapak CN }\end{array}\end{array}$

$-\underset{1}{\mathrm{~S}} \mathrm{i}-\mathrm{O}-\underset{1}{\mathrm{~S}} \mathrm{i}-\left(\mathrm{CH}_{2}\right)_{3} \mathrm{NH}_{2}$

$\geq_{\mathrm{Si}}-\mathrm{Ph}_{\mathrm{Ph}}$

$\stackrel{+}{\mathrm{S} i}-\left(\mathrm{CH}_{2}\right)_{17} \mathrm{CH}_{3}$

Micropak $\mathrm{NH}_{2}, \mu$-Bondapak $\mathrm{NH}_{2}$

Bondapak Phenyl Corasil

Lichrosorb RP-I8, Permaphase ODS, Zorbax ODS, Bondapak $\mathrm{C}_{\mathrm{I} 8}$ TSK-GEL LS-4IO, Perisorb RP $-\mathrm{I} 8$

\section{3. ポーラスポリマー充てん剂}

ポーラスポリマーは, 先に述ベたシリカゲル, シリカ
ゲル ODS と並んで化粧品分野の分析によく用いられる 充てん剤の一つである。一般にはポーラスポリマーは移 動相の種類により, 吸着, 分配, サイズ排除などの目的 に利用することができる。ポーラスポリマーはスチレン や酢酸ビニルとジビニルベンゼンの共重合体のものが多 い。市販品はつぎのようなものがある。

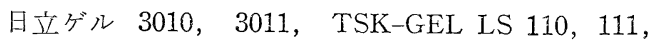
Polymer HP255 etc.

つぎに，これらの充てん剂を利用するとあたって，順 相と逆相クロマトグラフィ一の概念を明らか《して特く ことが便利と思われるので，その概略について記述する ことにする。

\section{II. 順相之視相クロマトゲラフィーについて}

順相クロマトグラフィーとは一般的には極性の小さい 移動相之極性の大きい固定相の組合せを言い，比較的極 性の大きい試料の分離塥している。一方逆相クロマト グラフィーは極监の大きい移動相之極性の小さい固定相 の組合せの場合堂いう，比較的極性の小さい試料または 順相クロマトグラフィーでは溶出しない高い極览の物質 の分離倍適している。Fig.-1 に分離の様子を模式的に 示した。順相 (Normal phase) クロマトグラフィーで はこの図に示すように極性の小さい物質が早く溶出さ れ，逆相 (Reversed Phase) クロマトグラフィーでは その逆である。

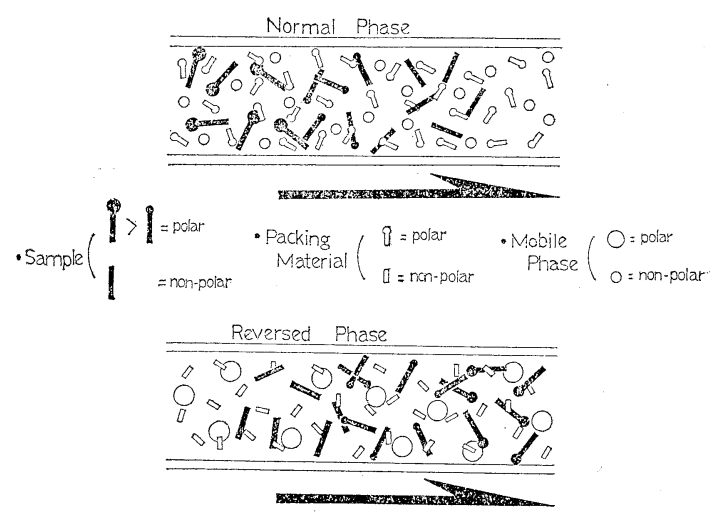

Fig. -1

その1例を Fig.-2 に示した。1 progegesterone, 2 Teststerone, 3 19-Norteststerone の順相括よび 逆相クロマトグラフィーによって分離した例である. 左 側が順相で右側が逆相である。 
化粧品関連分野における液体クロマトグラフィーの応用

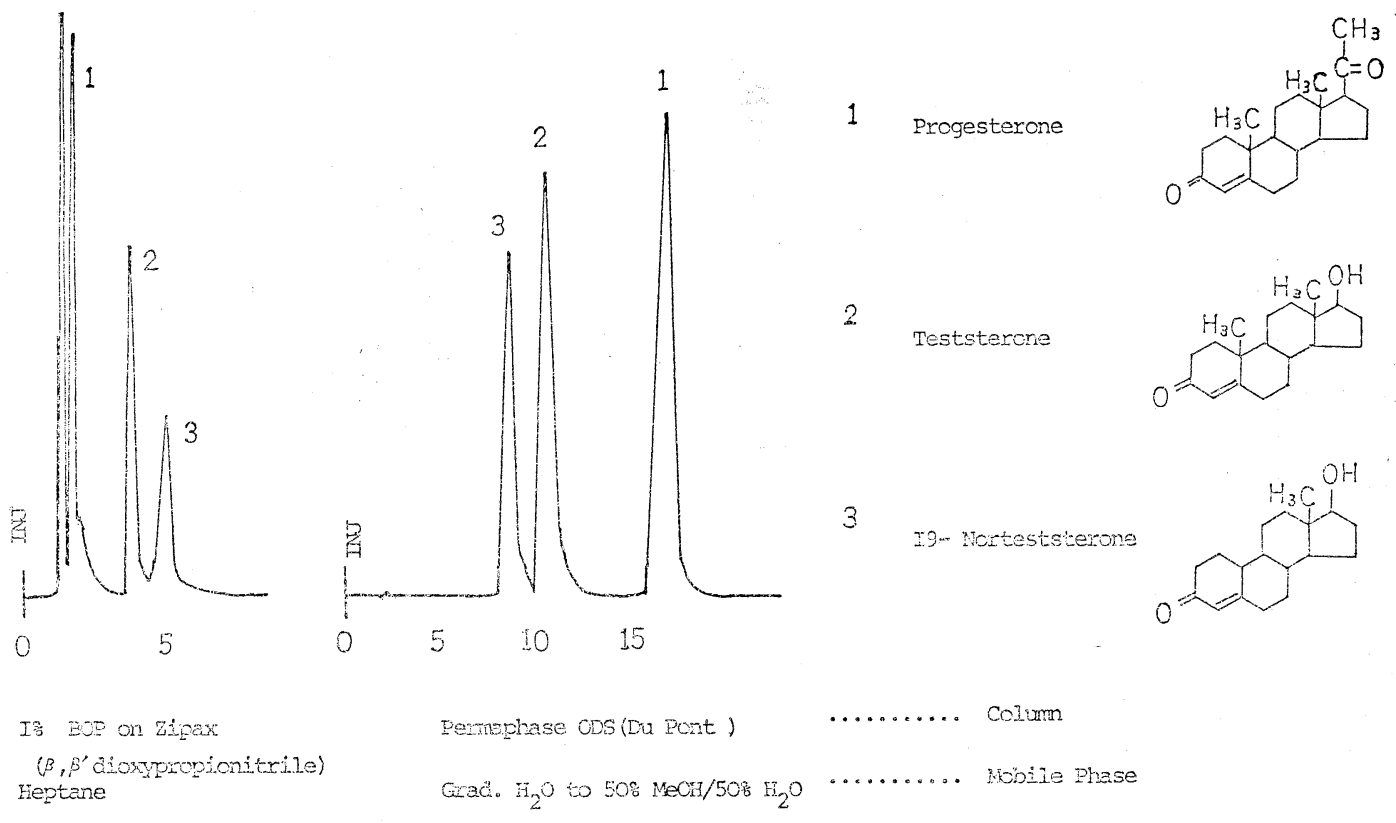

(J. Cucn. Eci., 9, 5I3, (J97I) )

Fig. -2

III. 化粧品関連物質の応用例について

Fig.-3 に示すように, すでに Newburger's Manual. of Cosmetic Analysis 2nd Edition (AOAC) K为, 化
粧品中の防應剂などの定量法に KPLC を利用したもの が記戴されている。Table-I に最近のこの分野沈和ける 応用例定示したが，今後ますます HPLC ほ利用される ことになるであうう。

Newburger's Manual of Cosnetic Analysis 2nd Edition

Determination of Freservatives in Cosmetics

Separation of: Vetriyl and Propyl Paraben ; Vydac reverse phase packing material

I.S. ; Ethyl paraben/EtOH

UV detector (254 $\mathrm{nm}$ )

Mobile Ehase; Methanol-water $(2: 8)$

Separation and Identification of Carbanilides, Salicylanilides, Hexachlorophene,

and Irgasan $\mathrm{DP} 300$

; Corasil II

254 rim uv detector, refractive incex detector

Mobile phase; Isopropanol and Heptane

Analysis of Toothpastes

Determination of Saccharin by High pressure Iiquid Chromatography ;

DuPont pelliculas strong anion exchanger (SAX)

$254 \mathrm{~nm}$ UV detector

Mobile phase ; O.OIO $\mathrm{M}$ sotium borate and O.OI5M

sodium nitrate ( $\mathrm{pH}(.2)$

Fig. -3

J. Soc. Cosmet. Chem. Japan. Vol. 16, №.1 1982 
Table-I 化粧品関連物質の応用例

\begin{tabular}{|c|c|c|c|c|}
\hline 物 簙 名 & 充 填 削 & 移 & 泚定波镸 & 文 献 \\
\hline 殺菌・防墔剂 & & & & \\
\hline Hexachlorophene & Sil-X & n-Hexane: butylchloride $=55: 45$ & uv $254 \mathrm{~nm}$ & 1 \\
\hline $\begin{array}{l}\text { フルキル安息香 } \\
\text { 酸エステル }\end{array}$ & $\begin{array}{l}\text { Hitachi gel } \\
\# 3010\end{array}$ & $\mathrm{MeOH}: \mathrm{H}_{2} \mathrm{O}=90: 10$ & 254 & 2 \\
\hline $\begin{array}{l}\mathrm{p} \text {-ヒドロキシ安 } \\
\text { 息香酸とその } \\
\text { ステル }\end{array}$ & $\begin{array}{r}\mu \text {-Bondapak } \\
\text { Cis }_{1 s}\end{array}$ & $\begin{array}{l}\mathrm{CH}_{3} \mathrm{CN}: 1 \text {-Heptane sulfonic acid } \\
\quad=35: 65\end{array}$ & 254 & 3 \\
\hline $\begin{array}{l}\mathrm{p} \text {-オキシ安息香 } \\
\text { 酸エステル }\end{array}$ & $\begin{array}{r}\text { Spherisorb } \\
\text { ODS }\end{array}$ & $\mathrm{H}_{2} \mathrm{O} \rightarrow 99 \% \mathrm{MeOH}$ & 254 & 4 \\
\hline $\begin{array}{l}\text { 臭化サリチルフ } \\
\text { ニリト }\end{array}$ & $\begin{array}{r}\text { Partisil } \\
\text { 10-ODS }\end{array}$ & $\mathrm{MeOH}: \mathrm{H}_{2} \mathrm{O}=7: 3$ & 254 & 5 \\
\hline $\begin{array}{l}フ ェ ノ ー ル と レ \\
\text { テルンノール }\end{array}$ & $\begin{array}{r}\mu \text {-Bondapak } \\
C_{18}\end{array}$ & $\begin{array}{l}0.02 \mathrm{M} \mathrm{NH}_{4} \mathrm{HCO}_{3}(\mathrm{pH} 7.67) / \\
10 \% \mathrm{MeOH}\end{array}$ & 254 & 6 \\
\hline $\begin{array}{l}\text { 軟哮中の安息票 } \\
\text { 酸およびサリチ } \\
\text { 儿酸 }\end{array}$ & $\begin{array}{c}\mu-\text { Bondapak } \\
\mathrm{C}_{\mathrm{ts}}\end{array}$ & $0.02 \mathrm{M} \mathrm{KH}_{2} \mathrm{PO}_{4} / 10 \% \mathrm{MeOH}$ & 254 & 7 \\
\hline 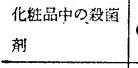 & Corasil $\mathbb{I}$ & インブロパノール/へプタン & $U V$ & 8 \\
\hline $\begin{array}{l}\text { メチルプロピル } \\
\text { ベラ゙゚ン }\end{array}$ & $\begin{array}{l}\text { Vydac reversed } \\
\text { phase packing } \\
\text { material }\end{array}$ & $\mathrm{MeOH}: \mathrm{H}_{2} \mathrm{O}=80: 20$ & $\begin{array}{l}\text { Chromato- } \\
\text { ronixmod- } \\
\text { el } 200 \mathrm{UV} \\
(254)\end{array}$ & 9 \\
\hline 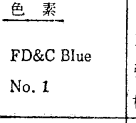 & \begin{tabular}{|l|} 
Dupont \\
強フニオン交換 \\
澍脂(SAX)
\end{tabular} & $\begin{array}{l}\text { 1) } 0.01 \mathrm{M} \mathrm{Na}_{2} \mathrm{~B}_{4} \mathrm{O}_{7} \\
\text { 2) } 0.25 \mathrm{M} \mathrm{NaClO}_{4}-0.01 \mathrm{M} \mathrm{Na2}_{4} \mathrm{O}_{2} \\
\text { (グシシメントカ式) }\end{array}$ & & 10 \\
\hline $\begin{array}{l}\text { FD\&C Blue } \\
\text { No. } 2\end{array}$ & $"$ & " & & 11 \\
\hline $\begin{array}{l}\text { FD\&C Yellow } \\
\text { No. } 5\end{array}$ & $"$ & $\begin{array}{l}\text { 1) } 0.01 \mathrm{M} \mathrm{Na}_{2} \mathrm{~B}_{4} \mathrm{O}_{7} \\
\text { 2) } 0.20 \mathrm{M} \mathrm{NaClO}+-0.01 \mathrm{M} \mathrm{Na}_{4} \mathrm{O}_{7} \\
\text { (グラジントナ式) }\end{array}$ & & 12 \\
\hline $\begin{array}{l}\text { FD\&C Yellow } \\
\text { No. } 5\end{array}$ & \begin{tabular}{|l|} 
Dupont \\
強フニオン交 \\
樹脂 $(\mathrm{SAX})$ \\
\end{tabular} & $\begin{array}{l}\text { 1) } 0.01 \mathrm{M} \mathrm{Na}_{2} \mathrm{~B}_{4} \mathrm{O}_{T} \\
\text { 2) } 0.10 \mathrm{M} \mathrm{NaClO}++0.01 \mathrm{M} \mathrm{Naz} \mathrm{B}_{4} \mathrm{O}_{T} \\
\text { (グラジンント方式) }\end{array}$ & 254 & 13 \\
\hline " & $\begin{array}{l}\text { pak } \mathrm{C}_{\mathrm{I}} \mathrm{B} \\
\text { - }\end{array}$ & $\begin{array}{l}\text { Methanol : } \mathrm{H}_{2} \mathrm{O}: \mathrm{HCOOH} \\
=400: 400: 1\end{array}$ & & 14 \\
\hline $\begin{array}{l}\text { FD\&C Yellow } \\
\text { No. } 6\end{array}$ & 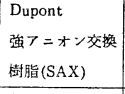 & $\begin{array}{l}\text { 1) } 0.01 \mathrm{M} \mathrm{Na} \mathrm{Na}_{4} \mathrm{O}_{\tau} \\
\text { 2) } 0.01 \mathrm{M} \mathrm{Na2B} \mathrm{O}_{\tau}-0.50 \mathrm{M} \mathrm{NaC2O} \text {. } \\
\text { (グラシェント方式) }\end{array}$ & & 15 \\
\hline " & " & " & uv 254 & 16 \\
\hline " & $"$ & $\vdots$ & 365 & 17 \\
\hline " & " & " & uv & 18 \\
\hline $\begin{array}{l}\text { FD\&C Red } \\
\text { No. } 2\end{array}$ & " & $\begin{array}{l}\text { 1) } 0.01 \mathrm{M} \mathrm{Na} \mathrm{B}_{4} \mathrm{O}_{\tau} \\
\text { 2) } 0.2 \mathrm{M} \mathrm{NaClO}+0.01 \mathrm{M} \mathrm{Na}_{4} \mathrm{~B}_{4} \mathrm{O}_{\tau} \\
\text { (グラジントカ式) }\end{array}$ & & 19 \\
\hline$"$ & $"$ & $\begin{array}{l}\text { 1) } 0.01 \mathrm{M} \mathrm{Na}_{2} \mathrm{~B}_{4} \mathrm{O}_{7} \\
\text { 2) } 0.01 \mathrm{M} \mathrm{Na}_{2} \mathrm{~B}_{4} \mathrm{O}_{2}-2 \mathrm{M} \mathrm{NaC} 2 \mathrm{O} \text {. } \\
\text { (グラジント方式) }\end{array}$ & 254 & 20 \\
\hline $\begin{array}{l}\text { キサントン㮇䋦 } \\
\text { 体 }\end{array}$ & Micro pak CN & n-Hexane: Chices & 254 & 21 \\
\hline 油容性タール色 & $\begin{array}{l}\text { Lichrosorb } \\
\text { SI } 102\end{array}$ & $\begin{array}{l}\text { Conecave gradient tec. } \\
\text { A) (I) } 5 \% \mathrm{CHCl}_{3} / \mathrm{n} \text {-Hexane } \\
\text { (I) } 50 \% \mathrm{CHCl}_{3} / \mathrm{n} \text {-Hexane } \\
\text { B) } 9 \%(\mathrm{~V} / \mathrm{V}) \text { Acetone / Hexane }\end{array}$ & 430 & 22 \\
\hline
\end{tabular}

\begin{tabular}{|c|c|c|c|c|}
\hline 物 斦 & 充 填削 & 動 & 則定波長 & 安 献 \\
\hline \begin{tabular}{l|} 
化胜品用タール \\
色素
\end{tabular} & $\begin{array}{r}\text { TSK GEL } \\
\text { LS - } 212 \\
\end{array}$ & $0.05 \%$ sulfuric acid / methanol & 500 & 23 \\
\hline " & $\begin{array}{r}\text { TSK GEL } \\
\text { LS - } 140 \\
\end{array}$ & $\begin{array}{l}0.1 \% \mathrm{CH}_{3} \mathrm{COOH} / \mathrm{MeOH}: 0.1 \% \\
\text { triethylamine } / \mathrm{MeOH}=9: 1\end{array}$ & 254 & 24 \\
\hline 合成食用色素 & silicagel-ODS & $\begin{array}{l}0.2 \%\left(\mathrm{NH}_{4}\right) \mathrm{CO}_{3} \rightarrow \mathrm{MeOH} \\
\text { linear grad }\end{array}$ & 254 & 25 \\
\hline 合成色素 & $\begin{array}{l}\text { Lichrosorb } \\
\text { RP-8 with } \\
\text { cetrimide }\end{array}$ & $\begin{array}{l}25 \%(\mathrm{~W} / \mathrm{V}) \text { n-Propanol, } 0.5 \%(\mathrm{~W} / \mathrm{V}) \\
\text { Cetrimide, } 0.01 \mathrm{M} \mathrm{NaBr}, 0.05 \mathrm{M} \\
\mathrm{NaH}_{2} \mathrm{PO}, \mathrm{pH} 3.5\end{array}$ & 243 & 26 \\
\hline $\begin{array}{l}\text { カブセル中の色 } \\
\text { 素 }\end{array}$ & $\begin{array}{l}\text { Permaphase } \\
\text { ODS }\end{array}$ & $\begin{array}{l}\text { 臭化セチルトリイテルフンモニウムブ } \\
\text { ロマイト MeOH } \\
\text { (クラジント方式) }\end{array}$ & UV 254 & 27 \\
\hline $\begin{array}{l}\text { キサンテン系染 } \\
\text { 料 }\end{array}$ & 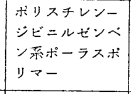 & $\begin{array}{l}\mathrm{HClO}+ \\
\mathrm{H}_{2} \mathrm{O} \\
\mathrm{CH}_{3} \mathrm{CN}\end{array} / \mathrm{CH}_{3} \mathrm{OH}$ & & 28 \\
\hline $\begin{array}{l}\text { FD\&C Red No. } \\
40 \text { 中の 未庶 } \\
\text { 中間体な } \\
\end{array}$ & \begin{tabular}{|l|} 
Dupont \\
Zipax SAX \\
\end{tabular} & $\begin{array}{l}0.01 \mathrm{M} \mathrm{Na}_{2} \mathrm{~B}_{4} \mathrm{O}_{7} \\
0.2 \mathrm{M} \mathrm{NaClO}_{4} / 0.01 \mathrm{M} \mathrm{Na}_{2} \mathrm{~B} \mathrm{O}_{7}\end{array}$ & UV & 29 \\
\hline $\begin{array}{l}\text { Polyethyleneg- } \\
\text { Iycol }\end{array}$ & Zorbax SIL & $\begin{array}{l}\text { (ケ゚ラジンント方式) } \\
\text { n-Hexane : acetone }=75: 25 \\
\rightarrow \text { フセトン }\end{array}$ & FID & 31 \\
\hline $\begin{array}{l}\text { Polyoxyethy * } \\
\text { lene 系界面活性 } \\
\text { 敞 }\end{array}$ & " & " & " & 32 \\
\hline " & Porasil 60 & $5 \% \mathrm{H}_{2} \mathrm{O}$ ーメチルメチルケトン & RI & 33 \\
\hline " & Corasil II & iso propanol $: \mathrm{n}$-Hexane $=5: 95$ & RI & 34 \\
\hline $\begin{array}{l}\text { alkylbenzene } \\
\text { sulfonate } \\
\text { (河川水) }\end{array}$ & $\begin{array}{l}\text { TSK GEL } \\
\text { LS }-310\end{array}$ & $\begin{array}{l}\text { Stepwise elution sys. } \\
\text { n-Hexane : EtOH }=8: 2 \\
0.01 \% \mathrm{H}_{2} \mathrm{SO}_{4}-(\mathrm{n} \text {-Hexane : ethanol })\end{array}$ & 225 & 35 \\
\hline $\begin{array}{l}\text { 低䢁アルキルベ } \\
\text { 比ンスホン } \\
\text { 酸塩 }\end{array}$ & $\begin{array}{l}\text { TSK Gel } \\
\text { LS- } 222\end{array}$ & $0.2 \mathrm{M}-\mathrm{HClO}_{4}-\mathrm{MeOH} / \mathrm{H}_{2} \mathrm{O}$ & 220 & 37 \\
\hline グリセりド等 & $\begin{array}{l}\text { Micro pak } \\
\text { SH - } 10\end{array}$ & $\begin{array}{l}\text { Hexane }: \mathrm{CHCl}_{3}=9: 1 \\
\rightarrow \mathrm{EtOH}(3 \% \mathrm{EtOH} / \mathrm{min})\end{array}$ & FID & 38 \\
\hline $\begin{array}{l}\text { ポリエチレング } \\
\text { リーール200 }\end{array}$ & $\begin{array}{c}\text { A) Shodex A } 802 \\
\text { GPC-Gel } \\
\text { B) JAIGEL } 2 \mathrm{H} \\
\text { (Shodex H } 202 \\
\text { 相当) }\end{array}$ & $\begin{array}{l}\text { A) } \mathrm{THF} \\
\text { B) } \mathrm{CHCl}_{3}\end{array}$ & 屈析計 & 39 \\
\hline $\begin{array}{l}\text { ポリェチレング } \\
\text { リニール }\end{array}$ & $\begin{array}{l}\text { TSK-GEL } \\
\text { G } 2000 \mathrm{PW}\end{array}$ & & $\mathrm{RI}$ & 40 \\
\hline $\begin{array}{l}\text { ポリメチレング } \\
\text { リーール }\end{array}$ & $\left(\begin{array}{l}\text { Separon } 40-\mathrm{S} \\
\mathrm{C}_{13} \text { deriv. of } \\
\text { macroporous } \\
\text { Copolymer of } \\
\text { 2-hydroxyethyl } \\
\text { methacrylate } \\
\text { and ethylene } \\
\text { dimethacrylate }\end{array}\right)$ & $\mathrm{MeOH}: \mathrm{H}_{2} \mathrm{O}=95: 5$ & RI & 41 \\
\hline $\begin{array}{l}\text { ポリオキシエチ } \\
\text { レン系界面活性 } \\
\text { 剂とその分解物 }\end{array}$ & $\begin{array}{c}\mu-\text { Bondapak } \\
\text { Cis }_{1 s}\end{array}$ & $\begin{array}{l}68 \% \mathrm{MeOH} \\
16 \% \mathrm{CH}_{2} \mathrm{Cl}_{2} \\
16 \% \mathrm{H}_{2} \mathrm{O} \\
0.2 \% \mathrm{CH}_{3} \mathrm{COOH} \\
\end{array}$ & $\mathrm{RI}$ & 42 \\
\hline $\begin{array}{l}\text { Sulfobetaine 系 } \\
\text { 界面活性削 }\end{array}$ & " & $\mathrm{MeOH}: \mathrm{H}_{2} \mathrm{O}=80: 20$ & RI & 43 \\
\hline $\begin{array}{l}\text { フルキルヘンシ } \\
\text { ルジチルフン } \\
\text { モニウムクロリ } \\
\text { トとフルキルピ } \\
\text { リジニウムハラ } \\
\text { イド }\end{array}$ & $\begin{array}{c}\text { Hitachi gel } \\
3011\end{array}$ & $0.5 \mathrm{M} \mathrm{HClO}, / \mathrm{MeOH}$ & $\begin{array}{l}\text { UV } \\
220 \\
260\end{array}$ & 44 \\
\hline
\end{tabular}




\begin{tabular}{|c|c|c|c|c|}
\hline 物 犋 名 & 充 填 郕 & 相 & 測定波辰 & 文 㳼 \\
\hline $\begin{array}{l}\text { イオン性、非イ } \\
\text { オン性活性剂同 } \\
\text { 族体 }\end{array}$ & \begin{tabular}{|l|} 
TSK GEL LS- \\
410 (オクタデシ \\
ルシリカ)
\end{tabular} & $\begin{array}{l}\mathrm{NaCl} 0.4 \mathrm{M} / \mathrm{L} \text { を含有するか } / \mathrm{MeOH} \\
=15 / 85\end{array}$ & 210 & 45 \\
\hline $\begin{array}{l}\text { モノ・シ・トリ } \\
\text { クリセライト遊 } \\
\text { 蜼酸 }\end{array}$ & $\begin{array}{l}\text { Partisil } \\
\text { PXS 10/25 } \\
\text { PAC }\end{array}$ & $\begin{array}{l}\text { ヘキサンークロロホルム } \\
\text { へキサンーアセトニトリルーCHCl } \\
\text { (グシシェント方式) }\end{array}$ & $\begin{array}{l}\mathrm{IR} \\
5.72 \\
\mu \mathrm{m}\end{array}$ & 46 \\
\hline 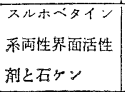 & $\begin{array}{l}\mu-\text { Bonda pak } \\
\text { Cis }_{18}\end{array}$ & $\begin{array}{l}\mathrm{MeOH}-\mathrm{H}_{2} \mathrm{O}=85: 15 \\
+\mathrm{CH}_{3} \mathrm{COOH}(0.2 \%)\end{array}$ & $\begin{array}{l}\text { 示善屈折 } \\
\text { 計 }\end{array}$ & 47 \\
\hline $\begin{array}{l}\text { モ・・シ・トリ } \\
\text { グリセロール }\end{array}$ & $\begin{array}{l}\text { Lichrosorb } \\
\text { DIOL }\end{array}$ & オクタソーインプロパール & 213 & 48 \\
\hline $\begin{array}{l}\text { エトオキシ化脂 } \\
\text { 肪フルニールお } \\
\text { よびフルキルフ } \\
\text { ×ーール類中の } \\
\text { Polyethylene } \\
\text { Glycol }\end{array}$ & $\begin{array}{l}\text { Bonda pak } \\
\mathrm{C}_{18} / \text { corasil }\end{array}$ & $\mathrm{CH}_{3} \mathrm{CN}: \mathrm{H}_{2} \mathrm{O}(65 / 35)$ & & 50 \\
\hline LAS 同族体 & \begin{tabular}{|l|} 
スチレンジビ二 \\
ルペビン系ボ \\
ーラスポリマー
\end{tabular} & $0.5 \mathrm{M} \mathrm{HClO}_{4}-\mathrm{MeOH}$ & & 51 \\
\hline $\begin{array}{l}\text { ホルモン } \\
\text { 副盈皮質ホルモ } \\
\because \\
\end{array}$ & $\begin{array}{l}\text { Hitachi } \\
\text { custom } \# 3010\end{array}$ & $\mathrm{H}_{2} \mathrm{O}: \mathrm{MeOH}=12.5: 87.5$ & 254 & 52 \\
\hline " & $\begin{array}{r}\text { Silica gel } \\
\mathrm{H}\end{array}$ & methylene chloride : $\mathrm{MeOH}=9: 1$ & 254 & 53 \\
\hline " & $\begin{array}{l}\text { 18-Cyanoethyl } \\
\text { silicone-Zipax }\end{array}$ & $\mathrm{MeOH}: \mathrm{H}_{2} \mathrm{O}=1: 99$ & 254 & 54 \\
\hline 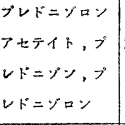 & $\begin{array}{l}\text { Zipax } \\
\text { 1\% BOP }\end{array}$ & THF : Heptane $=20: 80$ & 254 & 56 \\
\hline コルチコイド & Zorbax SIL & $\begin{array}{l}\text { methylene chloride : Methanol }: \mathrm{H}_{2} \mathrm{O} \\
=96: 2: 2\end{array}$ & 254 & 57 \\
\hline $\begin{array}{l}\text { エストロンとそ } \\
\text { の解導体 }\end{array}$ & $\begin{array}{l}\text { Hitachi } \\
\text { custom } \# 3010\end{array}$ & Methanol & 240 & 58 \\
\hline 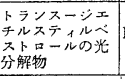 & $\begin{array}{l}\text { Perma phase } \\
\text { ETH }\end{array}$ & $\begin{array}{l}\text { 2-Propyl alcohol }: \mathrm{H}_{2} \mathrm{O} \\
=20: 80\end{array}$ & 254 & 60 \\
\hline $\begin{array}{l}\text { シメチルスチル } \\
\text { ベストロールと } \\
シ \text { シンストロー } \\
\text { ル }\end{array}$ & $\begin{array}{l}\text { Spherosil } \\
\text { XOA } 400\end{array}$ & & UV & 61 \\
\hline $\begin{array}{l}\text { DNS } \\
\text { エストロゲン }\end{array}$ & \begin{tabular}{|l} 
Lichrosorb \\
SI - 60 \\
\end{tabular} & $30 \%$ n-Heptane $/ \mathrm{CHCl}_{3}$ & \begin{tabular}{|l|} 
Flu.detec. \\
Ex220 \\
$420 \mathrm{~m}$ \\
440 \\
\end{tabular} & 62 \\
\hline エストロゲン & Zorbax ODS & $\mathrm{MeOH}: \mathrm{H}_{2} \mathrm{O}=65: 35$ & $\mathrm{UV}_{254}$ & 63 \\
\hline $\begin{array}{l}\text { 䤀酸ヒドロコル } \\
\text { チゾシ }\end{array}$ & $\begin{array}{l}\text { JASCO PACK } \\
\text { SV - } 02500\end{array}$ & $\mathrm{MeOH}: \mathrm{H}_{2} \mathrm{O}=6: 4$ & 242 & 64 \\
\hline $\begin{array}{l}\text { エチニルエスト } \\
\text { ラジオールなど }\end{array}$ & $\begin{array}{c}\text { Lichrosorb } \\
\text { RP - } 8 \\
\end{array}$ & $\mathrm{CH}_{3} \mathrm{CN}: \mathrm{H}_{2} \mathrm{O}=41: 59$ etc. & $\begin{array}{l}\text { UV } \\
\text { Ex 280 } \\
\text { Em305 }\end{array}$ & 65 \\
\hline $\begin{array}{l}\text { エチニル×スト } \\
\text { ラジオール }\end{array}$ & JASCO HP-01 & $\mathrm{MeOH}: \mathrm{H}_{2} \mathrm{O}=98: 2$ & 231 & 66 \\
\hline $\begin{array}{l}\text { 㗆筒中のブレド } \\
=\text { ソロン }\end{array}$ & " & $\mathrm{MeOH}$ & 242 & 67 \\
\hline $\begin{array}{l}\text { エストラジオー } \\
\text { ル,エチニルエ } \\
\text { ストラジオール }\end{array}$ & \begin{tabular}{|l|} 
Nucleosil \\
$5 \mathrm{NH}_{2}$, Lichro- \\
scrb NH2
\end{tabular} & $\begin{array}{l}\text { エターール } \\
\text { ヘキサン }\end{array}$ & $\begin{array}{l}\text { 蛍光検出 } \\
\text { 器 } \mathrm{E} \times 280 \\
\mathrm{Em} 305\end{array}$ & 68 \\
\hline $\begin{array}{l}\text { ピタミン } \\
\text { 油签性ピタミン }\end{array}$ & Vydac TM & Pentane $:$ THF $=97.5: 2.5$ & UV & 69 \\
\hline
\end{tabular}

\begin{tabular}{|c|c|c|c|c|}
\hline 物 質 名 & 充 填戍 & 移 & 刑定波長 & 文献 \\
\hline 製刘中のVA & $\begin{array}{l}\text { Permaphase } \\
\text { ODS }\end{array}$ & $\mathrm{MeOH}: \mathrm{H}_{2} \mathrm{O}=77: 23$ & $\begin{array}{l}\mathrm{UV}_{254} \\
\end{array}$ & 70 \\
\hline 油溶性ビタミン & Partisil- 5 等 & $\begin{array}{l}\text { 1) n-Hexane : } \mathrm{CHC}_{3}=85: 15 \\
\text { 2) n-Hexane : } \mathrm{CHC}_{3}: 50 \% \mathrm{H}_{2} \mathrm{O}- \\
\text { Sat. isopropanol }=88: 10: 2 \\
\text { (グラジェント方式) }\end{array}$ & UV 254 & 71 \\
\hline ビタミンA $\mathrm{A}$ 類 & Corasil II & $\mathrm{CHCl}_{3}$ & RI & 72 \\
\hline 水容性ビタミン & Zipax. SCX等 & $0.05 \mathrm{M} \mathrm{NaH}_{2} \mathrm{PO}_{4}+0.05 \mathrm{M} \mathrm{KH}_{2} \mathrm{PO}$ & $\begin{array}{l}\text { UV } \\
254\end{array}$ & 73 \\
\hline $\begin{array}{l}\text { トコフェロール } \\
\text { 異性体 }\end{array}$ & $\begin{array}{l}\text { Jasco pack } \\
\text { wc- } 03-500\end{array}$ & $\begin{array}{l}\text { Diisopropylether: } \mathrm{n} \text {-Hexane } \\
=2: 98\end{array}$ & & 74 \\
\hline " & Corasil 【 & 5\% Diisopropylether / $\mathrm{n}$-Hexane & & 76 \\
\hline 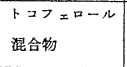 & $\begin{array}{c}\text { Permaphase } \\
\text { ODS }\end{array}$ & $\begin{array}{l}80 \% \mathrm{MeOH} \rightarrow 85 \% \mathrm{MeOH} \\
\text { (グラジェント方式) }\end{array}$ & $\begin{array}{l}\text { UV } \\
254\end{array}$ & 77 \\
\hline VA, D, E & Vydac TM & Pentane $: \mathrm{THF}=97.5: 2.5$ & 254 & 78 \\
\hline ビタミン凮 & Zipax HCP & $\mathrm{MeOH}: \mathrm{H}_{2} \mathrm{O}: \mathrm{H}_{3} \mathrm{PO}_{4}=79: 21: 0.1$ & 254 & 79 \\
\hline $\begin{array}{l}\text { トニフェロール } \\
\text { とその誘導体 }\end{array}$ & $\begin{array}{l}\text { Hitachi } \\
\text { Custom } \$ 3040 \\
\end{array}$ & $\begin{array}{l}\text { n-Hexane : Diisopropylether } \\
\quad=90: 10\end{array}$ & 295 & 81 \\
\hline ピタ:ン & $\begin{array}{c}\text { Permaphase } \\
\text { ODS }\end{array}$ & $\begin{array}{l}\text { Liner gradient. } \\
\text { elu. sys. } \\
\mathrm{H}_{2} \mathrm{O} \rightarrow 100 \% \mathrm{MeOH}\end{array}$ & 254 & 82 \\
\hline 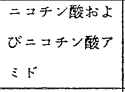 & $\begin{array}{c}\mu \text {-Bonda- } \\
\text { pak } \mathrm{C}_{18}\end{array}$ & $\begin{array}{l}2.0 \times 1 \sigma^{-3} \mathrm{M} \text { dioctyl } \\
\text { Sodium Sulfosuccinate }(\mathrm{pH}=2.5 \mathrm{~K} \text { 調 } \\
\text { 整) } / \text { water : MeOH }=1: 1\end{array}$ & 254 & 83 \\
\hline ピタミン & $\begin{array}{l}\text { Hitachi gel } \\
3011\end{array}$ & $\mathrm{MeOH}:$ ×チルメーテル & UV & 84 \\
\hline 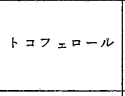 & Micro pak SI & $\begin{array}{l}\text { 1) Hexane } \\
\text { 2) Diisopropylether } \\
\text { (ダラジント方式) }\end{array}$ & 297 & 85 \\
\hline$"$ & Partsil pxsio & $0: 3 \% \mathrm{MeOH} /$ Hexane & \begin{tabular}{|l|} 
Fluores- \\
cent det. \\
Ex 295 \\
Em340 \\
\end{tabular} & 86 \\
\hline 脂溶性ビタミン & $\begin{array}{c}\text { Vydac reverse } \\
\text { phase }\end{array}$ & $\mathrm{MeOH}: \mathrm{H}_{2} \mathrm{O}=9: 1$ & 254 & 87 \\
\hline " & $\begin{array}{c}\mu-\text { Bondapak } \\
\mathrm{C}_{18} \\
\end{array}$ & $\mathrm{MeOH}: \mathrm{H}_{2} \mathrm{O}=95: 5$ & 280 & 88 \\
\hline ビタミンA, E & $\begin{array}{c}\text { Spherisorb } \\
\text { ODS }\end{array}$ & $\mathrm{H}_{2} \mathrm{O}: \mathrm{MeOH}=10: 90$ & 280 & 89 \\
\hline ピタミンD & $\begin{array}{r}\text { Lichrosorb } \\
\text { SI } 60 \\
\end{array}$ & $\begin{array}{r}50 \% \mathrm{H}_{2} \mathrm{O}-\text { Sat. Hexane : } \\
\text { isopropanoI }=99: 1\end{array}$ & 265 & 90 \\
\hline ビタミン $\mathrm{D}_{3}$ & $\begin{array}{c}\text { Lichrosorb } \\
\mathrm{NH}_{2}\end{array}$ & Hexane : isopropanol $=98: 2$ & 254 & 91 \\
\hline 油溶性ビタミン & Micro-pak CN & $\begin{array}{l}\text { ×チンクロライト:CHC } \ell_{3}: \\
\text { n-Hexane }=3: 2: 15\end{array}$ & & 92 \\
\hline 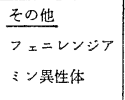 & Zorbax sil & $\mathrm{MeOH}: \mathrm{CHC}_{3}=0.7: 99.3$ & 254 & 93 \\
\hline " & Coracil II & $\mathrm{MeOH}:$ Cyclopentan $5: 95$ & 254 & 94 \\
\hline " & $\begin{array}{r}\text { Spherisorb } \\
\text { s5 - ODS } \\
\end{array}$ & $\begin{array}{l}0.02 \mathrm{M} \text { ammonium formate in } \\
30 \% \mathrm{MeOH}(\mathrm{pH} 6.4)\end{array}$ & 254 & 95 \\
\hline $\begin{array}{l}\text { フミノフニーー } \\
\text { ル類 }\end{array}$ & $\begin{array}{c}a \text {-Bonda pak } \\
\mathrm{C}_{18} \\
\end{array}$ & $0.1 \mathrm{mmol} / \mathrm{d} . \mathrm{m}^{3} \quad \mathrm{HC} \ell \mathrm{D}_{4}$ & \begin{tabular}{|l|} 
Voltam- \\
metric \\
detector \\
UV 254 \\
\end{tabular} & 96 \\
\hline 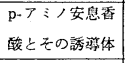 & Partisil SAX & pH3.5 0.1M Sodium formate buff. & 254 & 97 \\
\hline $\begin{array}{l}\text { オキンカルボン } \\
\text { 酸ジカルボン酸 }\end{array}$ & \begin{tabular}{|l} 
Dowex 1-X8 \\
(Suiphate form)
\end{tabular} & oH $6.5 \quad 0.03 \mathrm{M} \mathrm{Na}_{2} \mathrm{SO}_{4}$ & \begin{tabular}{|l|}
$\begin{array}{l}\text { Spectro- } \\
\text { photo } \\
\text { meter }\end{array}$ \\
\end{tabular} & 98 \\
\hline $\begin{array}{l}\text { ホスファティデ } \\
\text { イルコリン }\end{array}$ & $\begin{array}{c}\text { Lichrosorb } \\
\text { SI } 60\end{array}$ & & 206 & 99 \\
\hline
\end{tabular}




\begin{tabular}{|c|c|c|c|c|}
\hline 物 質 名 & 克 填 郕 & 動 & 做社波長 & 文 献 \\
\hline $\begin{array}{l}\text { チオグリコール } \\
\text { 酸 }\end{array}$ & $\begin{array}{r}\text { Chrompack } \\
5 \mathrm{RP}-18 \\
\end{array}$ & $\begin{array}{l}\mathrm{H}_{2} \mathrm{O}+\mathrm{MeOH}+\mathrm{PICA} \\
(\mathrm{NBD}-\mathrm{Cl}(7-\text { chloro-4 - nitro- } \\
\text { benzo- } 2 \text { oxo }-1,3 \text {-diazole }))\end{array}$ & 464 & 100 \\
\hline 卵黄リン脂颉 & Ultrasil- $\mathrm{NH}_{2}$ & $\begin{array}{l}\text { A) ヘキサソーイソブロパノール } \\
\text { B) ヘキサンーイソプロパノールー } \\
\text { イタノールー } \mathrm{H}_{2} \mathrm{O} \\
\quad \text { (グラシメント活出法) }\end{array}$ & 206 & 101 \\
\hline $\begin{array}{l}\text { モノテルベン } \\
\text { 類 }\end{array}$ & $\begin{array}{c}\text { Hitachi gel } \\
\# 3010\end{array}$ & メターール & $\begin{array}{l}\text { 示美屈折 } \\
\text { 計 }\end{array}$ & 102 \\
\hline $\begin{array}{l}\text { セスキテルペ } \\
\text { ン類 }\end{array}$ & " & イタノール: $\mathrm{H}_{2} \mathrm{O}=9: 1$ & $"$ & 103 \\
\hline 糢 & Hypersil-SAS & メタノール: $\mathrm{H}_{2} \mathrm{O} \quad(1: 1)$ & 260 & 104 \\
\hline $\begin{array}{l}\text { ペルガモット油 } \\
\text { ベルガブテン }\end{array}$ & Corasil II & ヘキサン：クロロホルム & 254 & 105 \\
\hline
\end{tabular}

\section{文献}

1. P. J. Porcaro et al, Anal.chem., 44, 1865(1972)

2. A. Nakae et al, J. Chromatogr., 120, 47 (1976)

3. N. D. Brown et al, ibid., 166, 316 (1978)

4. S. R. Bakalyar et al, ibid., 126, 327 (1976)

5. P. Cukor et al, ibid., 147, 496 (1978)

6. V. D. Gupta, J. Pharm. Sci., 65, 1706 (1976)

7. V. D. Gupta, ibid., 66, 110 (1977)

8. T. Wolf et al, J. of Soc. Costmet Chem., 24, 363 (1973)

9. F. A. Fitzpatrick et al, ibid., 26, 377 (1975)

10. D.M. Marmion, Handbook of U. S. Colorants for foods, drugs, and cosmetics (A Wileyinterscience pub.) 1979 P. 208

11. M. Singh et al, J. of AOAC., 58, 48 (1975)

12. D. M. Marmion, Handbook of U.S. Colorants for foods, drugs, and cosmetics (A Wileyinterscience Pub.)1979, P. 209

13. Bailey et al J. of AOAC., 61, 1404 (1978)

I4. D. P. Wittner, Anal. Chem., 47, 1422 (1975)

15. J. E. Bailey et al, J. of AOAC.,58, 609(1975)

16. D. M. Marmion et al, ibid., 58, 719 (1975)

17. D. M. Marmion et al, ibid., 60, 168 (1977)

18. M. Singh et al, ibid., 57, 358 (1974)

19. J. E. Bailey, ibid., 61, 1405 (1978)

20. M. Singh et al, ibid,, 60, 173 (1977)

21. K. Hostettmann et al, J. Chromatogr., 116, 201 (1976)

22. 大西ら, 分析化学., 26, 814 (1977)

23.24. 大西ら, ibid., 25, 353 (1977)

25. 野田ら, 食品衛生学雑誌, 18, 321 (1977)
26, C. P. Terweij-Groen et al, J. Chromatogr., 161, 69 (1978)

27. 赤田ら, 薬誌, 98, 1300 (1978)

28. 大津ら, 日本化学会誌, No. 4, 511 (1979)

29. A. Elizabeth et al, J. of AOAC.,64,324(1981)

31.32. 中村 淳ら, 日本化学会誌, No.8, 1342(1975)

33. K. J. Bombaugh et al, J. Chromatgr. Sci., 8, 560 (1970)

34. K. J. Bombaugh et al, ibid., 8, 657 1970)

35. 高野 敏ら, 油化学, 24, 389 (1975)

37. 中栄ら, 日本化学会誌, 1426 (1976)

38. K. Kiuchi et al, J. Chromatogr. Sci., 13, 461 (1975)

39. S. Mori, Anal. Chem., 50, 1639 (1978)

40. Y. Kato et al,J. Chromatogr., 153, 546(1978)

41. M. Coupkova et al, J. Chromatogr., 160, 73 (1978)

42. R.M. Cassidy et al, ibid., 126, 787 (1976)

43. N. Parris et al, Anal. Chem., 49. 2228(1977)

44. N. Nakae et a1, J. Chromatogr.,134, 459(1977)

45. N. Nakamura et al, J. AOCS., 58, 72 (1981)

46. Kathleen Payne-Wahl,J. of Chromatogr, 209, 61, (1981)

47. N. Parris et al, J. of AOCS., 55, 675 (1978)

48. T.Riisom et al, ibid.,55, 649 (1978)

50. L. P. Turner, J.AOCS, 53, 691 (1976)

51. A. Nakae et al, Jof Chromatogr., 152, 137 (1978)

52. 藤田一紀ら, 日本化学会誌, 463 (1975)

53. E. Godbille et al, J. Chromatogr. Sci., 12, 564 (1974)

54. M. C.Olson, J. Pharm. Sci., 62, 2001 (1973)

56. R. A. Henry et al, J. Chromatogr. Sci., 9, 513 (1971)

57. N. A. Parris, ibid., 12, 753 (1974)

58. 藤田一紀, 日本化学会誌, 846 (1975)

60. R. W. Roos, J. Pharm. Sci., 63, 594 (1974)

61. C. Hesse et al, Chromatographia., 10256 (1977)

62. R.W.Roos, J. Pharm. Sci., 67, 1735 (1978)

63. 福地ら, 薬刱学, 38, 102(1978)

64. 佐藤ら, 油化学, 26,228 (1977)

65. 枝ら, 衛生化学, 24,260 (1978)

66. 佐藤ら, 薬剤学, 38, 24(1978) 
67. 佐藤ら, ibid., 39, 20 (1979)

68. 大西ら, 分析化学, 28,82 (1979)

69. G. J. Krol et al, J. Chromatogr., 74, 43(1972)

70. 田部井ら, 薬学雑誌, 96, 669 (1976)

71. K. J. Bombaugh, J. Chromatogr., 107, 207(1 975)

72. K. J. Bombaugh, J. Chromatogr. Sci., 8, 657 (1970)

73. R. C. Williams et al, J. Chromatogr. Sci., 11, 619 (1973)

74. K.Abe et al, J.Nutr. Sci. Vit., 21, 183 (1975)

76. P. J. Van Nieberk, Anal. Biochem. 52., 536 (1973)

77. R. C. Williams et al, J. Chromatogr. Sci., 10, 494 (1972)

78. G. J. Krol et al., J. Chromatogr.,74, 43(1972)

79. R. C. Williams et al, J. Chromatogr. Sci., 10, 494 (1972)

81. 藤谷, 油化学, $25,860(1976)$

82. J. A. Schmit, et al, J. Chromatogr. Sci.,9, 645 (1971)

83. S. P. Sood. et al, J. Pharm. Sci., 66, 40 (1977)

84. 岡谷 5, 日本化学会第33秋季年会 (福岡) (昭50. 10)

85. M. Matsuo, Chem. Pharm. Bull., 25, 3381 (1977)

86. G. T. Vatassery et al, J. Chromatogr., 161, 299 (1978)

87. M. Osadca. et al,J. AOAC, 60, 993 (1977)

88. H. Cohen. et al, J. Agr. Food. Chem., 26, 1210 (1978)
89. P. Söderhjelm et al,J. Sci. Food. Agr., 29, 697 (1978)

90. J. N. Thompson, et al, J. AOAC, 60, 998 (1977)

91. Dennis G. Lein et al, ibid., 63, 1149 (1980)

92. S. Dulling et al, Anal. Chim. Acta., 127, 213 (1981)

93. P. R. Young et al, Anal. Chem., 47, 756 (1975)

94, R. E. Leitch et al, J. Chromatogr. Sci., 11, 105 (1973)

95. K. Sugden et a1, J. Chrmatogr., 149, 377 (1978)

96. 丸山5, 日杢化学会誌, 12, 1646 (1978)

97. N. D. Brown et al, J. Chromatogr., 121, 76 (1976)

98. L. Bengtsson et al, ibid., 61, 101 (1971)

99. A. Nasner et al, Fette. Seif. Austrichmittel., 83, 70 (1981)

100. J. Rooselaar et al, Int. J. of Cos. Sci., 3, 37 (1981)

101. V. L. Hanson, J. Chromatogr., 205, 393 (1981)

102. 中山充ら, 日本化学会誌，2314 (1973)

103. 中统ら, フレグランス ジャーナル, (No 6) 2, 52 (1974)

104. M. S. F. Ross, J. Chromatogr., 160, 199 (1978)

105. P. J. Porcaro, J. of the AOAC., 57, 145 (1974)

(昭和57年 3 月 30 日受理) 